\title{
EVALUAREA SCHIMBĂRILOR COMPONENTEI CHIMICE ȘI CALITĂṬII APEI ÎN BAZINUL HIDROGRAFIC AL FLUVIULUI NISTRU
}

\author{
Olga Jurminskaia, Nina Bagrin, Elena Zubcov
}

Institutul de Zoologie, ojur_aia@mail.ru

https://doi.org/10.53937/9789975151979.02

\begin{abstract}
Rezumat
Sunt analizate modificările compoziției chimice și calității apei fluviului Nistru, inclusiv lacul Dubăsari, pe baza cercetărilor de teren și prelucrarea în laborator a 76 probe colectate pe parcursul a patru sezoane hidrologice în anul 2020.
\end{abstract}

Cuvinte-cheie: fluviul Nistru, ecosisteme acvatice, parametri fizico-chimici, calitatea apei

\section{INTRODUCERE}

Compoziția apelor de suprafață depinde de mulți factori naturali din bazinul hidrografic al corpului de apă (geologic, meteorologic, hidrologic și biologic) și variază în funcție de fluctuațiile sezoniere ale scurgerii, condițiile meteorologice și nivelul apei. Intervenția umană are un impact semnificativ asupra calității apei, provocând modificări hidromorfologice precum construcția barajelor, reglarea debitului, drenarea zonelor umede. Deteriorarea calității apei datorată utilizării resurselor de apă în activitățile economice umane (deversarea apelor uzate menajere și industriale, utilizarea substantelor chimice pe terenurile agricole din bazinul de drenaj) are consecințe dăunătoare, cum ar fi deteriorarea resurselor biologice ale ecosistemelor acvatice, generarea riscului de afectare a sănătății umane, crearea obstacolelor pentru activitățile sportive și de recreere.

Principalele elemente ale monitoringului științific al ecosistemului acvatic sunt: măsurători la fața locului, colectarea și prelucrarea probelor, studiul și analiza rezultatelor obținute. Rezultatele analizelor unui eșantion instantaneu sunt valabile numai pentru locația și ora specifică la care a fost prelevată proba respectivă. Unul dintre obiectivele de monitorizare ar trebui să fie evaluarea calității apei, care este procesul de estimare a stării fizico-chimice, chimice și biologice a unui corp de apă în raport cu o stare de referință. Scopul lucrării prezentate este evaluarea stării ecologice a fluviului Nistru în limitele Republicii Moldova (inclusiv

\begin{abstract}
Changes in the chemical composition and water quality of the Dniester River, including the Dubossary Reservoir, were analyzed based on on-site measurements and laboratory processing of 76 water samples collected in four hydrological seasons in 2020.
\end{abstract}

Keywords: Dniester River, aquatic ecosystems, physical-chemical parameters, water quality

lacul de acumulare Dubăsari) pe baza unor parametri fizico-chimici, cum ar fi temperatura apei, starea de acidificare, oxigenul dizolvat și consumul biochimic de oxigen.

\section{MATERIALE ȘI METODE}

Materialul sau probele de apă din fluviul Nistru s-au colectat de echipa cercetătorilor Laboratorului Hidrobiologie si Ecotoxicologie în perioada de iarnă-primăvară-vară-toamnă 2020. În sezonul de iarnă, materialul a fost colectat la stațiile Naslavcea, Vălcineț, Soroca, Vadul lui Vodă, Varnița și Sucleia din Nistru și o probă de apă - din râul Răut de la staţia Ustia. Datorită introducerii unei stări de urgență în Republica Moldova în perioada 17 martie - 15 mai din cauza pandemiei COVID-19, expediția de primăvară a fost efectuată în a doua jumătate a lunii mai. În bazinul fl. Nistru, probele de primăvară au fost colectate la stațiile Naslavcea, Vălcineț, Soroca, Cocieri, Ustia, Vadul lui Vodă, Varnița, Palanca și din r. Bâc din zona de confluență cu fl. Nistru. În sezonul estival, au fost organizate trei expediții complexe pe fl. Nistru, dar din cauza situației de carantină, probele au fost prelevate numai de pe malul drept al Nistrului. În perioada de toamnă, expediția pe fl. Nistru a fost organizată în luna octombrie- la stațiile Naslavcea, Vălcineț, Soroca, Camenca, Vadul lui Vodă, Varnița, Palanca (fl. Nistru), Hârjău, Goieni și Cocieri (acumularea Dubăsari - de pe malul drept). Prelevarea probelor s-a efectuat conform standardelor națio- 
nale și Ghidului metodologic [1 - 4]. Determinarea parametrilor hidrochimici a fost realizată conform standardelor naționale [5 - 7]. Estimarea calității apei a ecosistemelor studiate $\mathrm{s}$-a efectuat pe baza Regulamentului [8]. Măsurarea temperaturii apei și fixarea oxigenului a fost efectuată la fața locului. Măsurarea pH-ului Laboratorul Hidrobiologie și Ecotoxicologie efectuează, de asemenea, in situ, utilizând Portable multi-parameter analyser $\mathrm{CON}$ SORT C5030.

\section{REZULTATE ȘI DISCUṬII}

\section{Condiții climatice și hidrologice}

Sezonul de iarnă 2020 a fost însoțit de temperaturi ridicate pe tot parcursul acestei perioade si de lipsa sau cantităti modeste ale precipitatiilor. Conform datelor SHS [9], această evolutie a proceselor meteorologice a determinat volumul scurgerii apelor cu valori sub normă, care sunt înregistrate o dată la 7 ani pentru fl. Nistru $(0,8-1,0$ $\mathrm{km}^{3}$, norma multianuală $-1,9 \mathrm{~km}^{3}$ ). Nivelurile de apă in fl. Nistru pe teritoriul RM depind de volumul debitelor de apă deversate din lacurile de acumulare Dnestrovsc (Ucraina). La data de 21 februarie, nivelul apei in lacul de acumulare Dnestrovsc a fost cu $4.40 \mathrm{~m}$ mai jos de NNR (Nivelul Normal de Retentie). Din punct de vedere meteorologic, primăvara anului 2020 a fost neomogenă privind regimului termic și s-a caracterizat, de asemenea, printr-un deficit de precipitatii. Vremea anormal de caldă a fost înregistrată în prima decadă a lunii martie. Cantitatea de precipitații în sezon a căzut neuniform. Un deficit semnificativ de precipitatii a fost observat și în aprilie, când valoarea lunară a acestora nu a depășit 5-25\% din norma lunară. În cea mai mare parte a teritoriului republicii, $\mathrm{s}-\mathrm{a}$ anuntat cod portocaliu de seceta hidrologică. Pe de altă parte, cantitatea precipitatiilor în luna mai pentru unele puncte de observații a constituit 185$290 \%$ din normă lunară.

Cele mai multe precipitații de vară au căzut în iunie: 75-165\% din media lunară. În iulie și august, s-a observat un deficit semnificativ de precipitatii pe cea mai mare parte a teritoriului tării. În legătură cu lipsa precipitațiilor atmosferice, nivelul apei în fl. Nistru a fost în scădere, iar pentru râurile mici s-a înregistrat secetă hidrologică (cod galben și portocaliu).

În luna octombrie, când s-a realizat expediția de toamnă pe fl. Nistru, vremea a fost anormal de caldă, cu precipitații. Temperatura medie lunară a aerului a constituit $(12,8-15,4)^{\circ} \mathrm{C}$, ceea ce pe o mare parte a teritoriului țării se semnalează pentru prima dată din toată perioada de observații. Cantitatea precipitațiilor căzute în decursul lunii pe $70 \%$ din teritoriul țării a constituit (115-275)\% din normă, dar în nordul țării, suma acestora a atins (310-435)\% din normă.

\section{Parametrii fizico-chimici}

Temperatura apei este unul dintre cei mai importanți factori abiotici care determină viteza și direcția proceselor fizice, chimice, biochimice și biologice în ecosistemele acvatice. Saturația apei cu oxigen și intensitatea proceselor producțional-distrucționale sunt determinate în mare măsură de temperatura apei. Regimul de temperatură al unui corp de apă este rezultatul mai multor procese care apar simultan, cum ar fi: radiație solară, evaporare, schimb de temperatură cu atmosfera, transfer de căldură prin scurgere, amestecare turbulentă de apă și altele. Temperatura fluviilor lungi variază, de asemenea, în funcție de schimbarea zonelor geografice prin care curg aceste râuri. În același timp, un factor important în formarea regimului de temperatură pe secțiunile locale ale cursului de apă este impactul antropic. Astfel, temperatura apei la momentul de colectare a probelor reprezintă rezultatul cumulat al proceselor naturale și impacturilor antropice.

În perioada februarie-octombrie 2020, dinamica temperaturii apei fl. Nistru, inclusiv lacul de acumulare Dubăsari, a variat în diapazonul $(2,7-$ $25,6)^{\circ} \mathrm{C}$. Debitul Nistrului în sezonul de iarnă 2020 a fost foarte redus, temperatura apei fiind destul de omogenă $(2,7-4,4)^{\circ} \mathrm{C}$ și care corespund conditiilor climatice ale sezonului. Debitul Nistrului a crescut în a doua decadă a lunii mai datorită precipitațiilor în sectorul superior al râului, dar nivelul apei pe teritoriul RM a rămas în limitele albiei minore. Dinamica spațială a temperaturii apei fl. Nistru în sezonul de primăvară-vară a demonstrat o stare tipică pentru sezonul cald: temperatura apei pe tronsonul Naslavcea-Vălcineț a fost mai scăzută decât valoarea medie la data de prelevare (Fig. 1). Rezultatele obținute confirmă faptul că secțiunea transfrontalieră a Nistrului (Naslavcea - Soroca) este cursul de apă modificat cu poluare termică, al cărui regim de temperatură este cauzat de funcționarea complexului hidroenergetic Dnestrovsc. Pentru sezonul de toamnă, poluarea termică a acestui sector are vectorul invers: temperatura apei este mai ridicată decât cea naturală. 


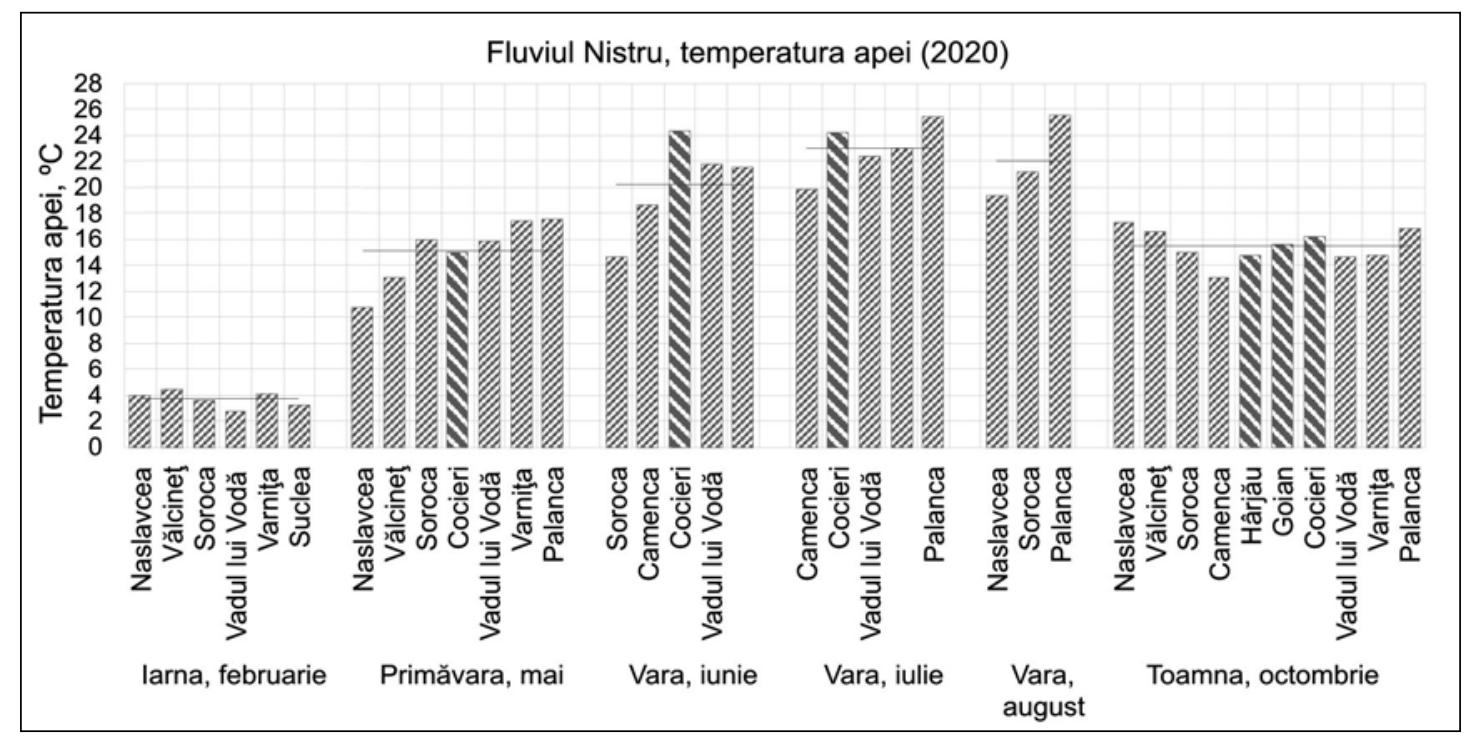

Fig. 1. Variațiile sezoniere ale temperaturii apei fluviului Nistru și lacului de acumulare Dubăsari (Hârjău, Goieni, Cocieri)

Ciclurile de dezvoltare a hidrobionților într-un ecosistem acvatic depind direct de regimul de temperatură al habitatului. Pentru hidrobionții cu un ciclu de viață scurt (zooplancton, fitoplancton), perturbarea dinamicii sezoniere a temperaturii apei este un factor nefavorabil care afectează dinamica ciclurilor de dezvoltare [10]. Pentru ihtiofauna Nistrului, apa rece în perioada de primăvară-vară, cât și lipsa de hrană adecvată, sunt factori limitatori care întârzie dezvoltarea peștilor cu 1,5-2 luni. Declanșarea migrațiilor de reproducere în această zonă climatică are loc în martie, la temperatura apei de aproximativ $5^{\circ} \mathrm{C}$, cu atingerea apogeului la $(10-17)$ ${ }^{\circ} \mathrm{C}$ (sfârșitul lunii aprilie - începutul lunii mai) și se încheie la $(22-24)^{\circ} \mathrm{C}$ (sfârșitul lunii iunie) [11]. Rezultatele monitoringului științific arată că regimul de temperatură al sectorului Nistrului în avalul complexului hidroenergetic Dnestrovsc (Naslavcea - Camenca) nu corespunde condițiilor adecvate (22 $-24)^{\circ} \mathrm{C}$ pentru încheierea ciclului de reproducere a ihtiofaunei în această zona a fluviului. Condiții adecvate sunt numai în acumularea Dubăsari și în aval (Fig. 1, iunie).

În condiții native (fără impact antropic), reacția activă a apei într-un corp de apă de suprafață este supusă fluctuațiilor sezoniere. În perioada de vegetație, modificările $\mathrm{pH}$-ului sunt strâns legate cu procesele de fotosinteză, precum și cu degradarea substanțelor organice. Pe de altă parte, acidificarea apelor de suprafață poate fi afectată de creșterea dioxidului de carbon, oxizilor de azot și sulfului din atmosferă, ce provoacă precipitații acide. Reacția activă (pH-ul)a apei fl. Nistru (inclusiv acumularea Dubăsari) în perioada analizată a anului 2020 a variat în limitele 7,09 - 8,69, ceea ce co- respunde claselor de calitate I - II conform Regulamentului [8]. Starea de acidificare a apelor Nistrului a fost analizată în paralel cu rezultatele obținute pentru afluenții lui principali de dreaptă (Fig. 2): r. Răut (st. Ustia, situată la $1,5 \mathrm{~km}$ de la confluența Răutului cu fl. Nistru - cca 4,3 km în aval de barajul Dubăsari), și r. Bâc (st. Gura Bâcului, situată la 0,75 $\mathrm{km}$ de la confluența Bâcului cu fl. Nistru - cca $1 \mathrm{~km}$ în amonte de Varnița).

Fluctuațiile spațiale a valorilor $\mathrm{pH}$-ului apei râului Nistru au fost mai puțin pronunțate în perioada de etiaj în timpul iernii- 8,56 $\pm 0,12$. În perioada de vară-toamnă, fluctuațiile $\mathrm{pH}$-ului apei de-a lungul profilului longitudinal al Nistrului este mult mai pronunțată: $7,89 \pm 0,80$. La stația Cocieri din acumularea Dubăsari, creșterea pHului vara este determinată de suprasaturația apei cu oxigen dizolvat ca rezultat al abudenței fitoplanctonului. Pentru prima dată, în ultimii ani, s-a observat o scădere semnificativă a pH-ului la stația Vadul lui Vodă atât vara (iulie), cât și toamna (octombrie).

Pe de altă parte, aceeași situație se observă și în zona confluenței r.Bâc, în apele caruia concentrația substanțelor biodegradabile este vizibil mai mare decât în fl. Nistru și valoarea $\mathrm{pH}$-ului scade la 7,25. Dar, datorită capacității de tampon, ecosistemul Nistrului deja la stația Varnița (la o distanță de cel mult $1 \mathrm{~km}$ ) neutralizează acest impact. Gradientul de creștere al pH-ului și pe sectorul Naslavcea-Camenca în octombrie. Astfel, rezultatele obținute demonstrează că reacția activă a apei fl. Nistrul în anul 2020 nu are o dinamică sezonieră clasică, dar fluctuează local datorită condițiilor climatice și hidrologice, și a impacturilor antropice. 


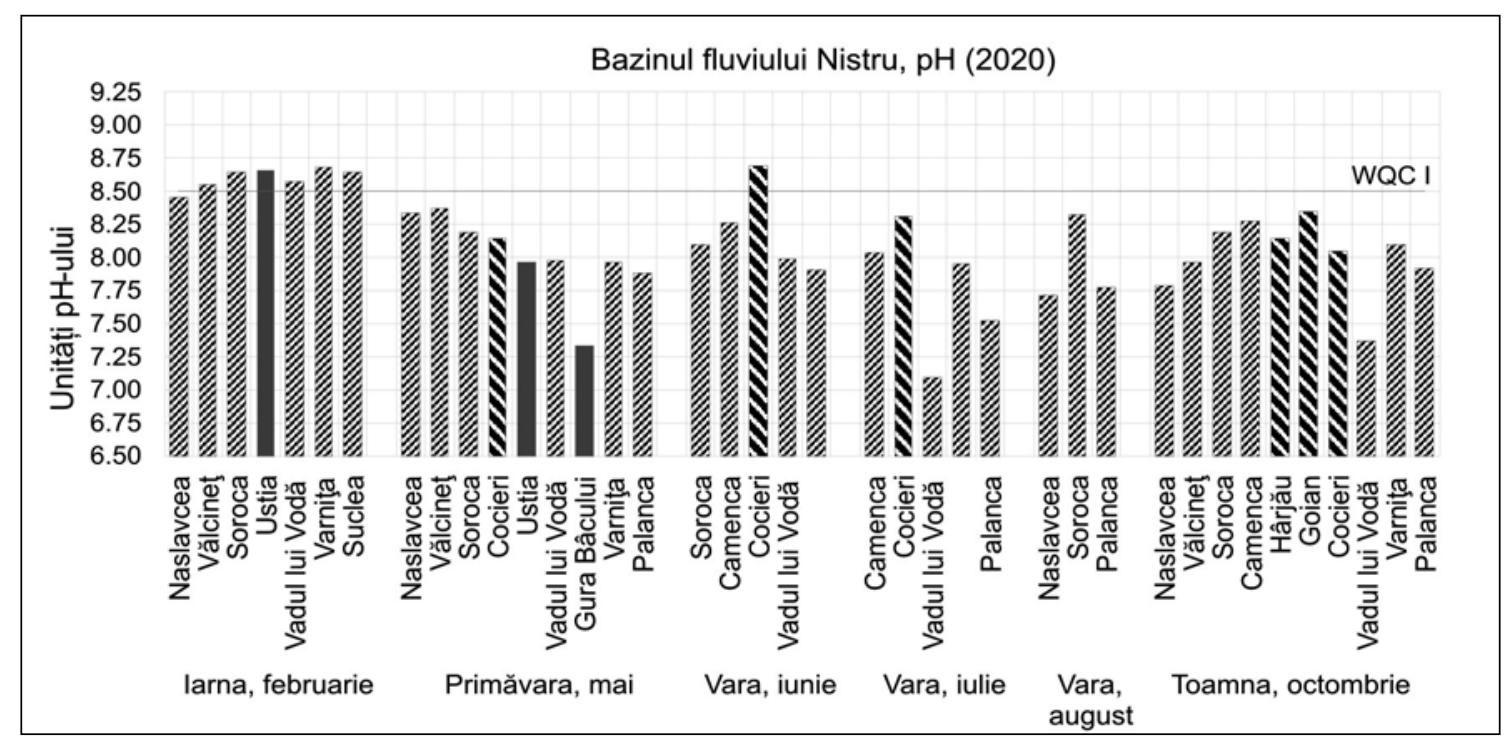

Fig. 2. Variațiile sezoniere ale reacției active a apei fluviului Nistru, lacului de acumulare Dubăsari (Hârjău, Goian, Cocieri) și afluenților de dreapta (Ustia - r.Răut, Gura Bâcului - r. Bâc)

Concentrația oxigenului într-un ecosistem acvatic depinde de mulți factori dintre care biotici şi abiotici, naturali și tehnogeni. Dintre factorii cu cea mai mare influență asupra concentrației oxigenului o exercită: temperatura apei, presiunea atmosferică, activitatea fotosintetică a producătorilor primari și turbulența fluxului. Deficiența oxigenului în habitatul acvatic poate fi provocată atât de temperatura ridicată a apei, cât și de prezența poluanților tehnogeni de o poluare secundară cauzată de descompunerea biomasei la sfârșitul sezonului de vegetație. Pentru orice combinație a acestor factori, concentrația oxigenului într-un corp de apă (sau sectorul său) este rezultatul unui echilibru dinamic între procesul de aerare (difuzie/convecție), producția și consumul oxigenului.

Solubilitatea oxigenului în apă scade odată cu creșterea altitudinii, temperaturii și salinității apei, precum și cu scăderea presiunii atmosferice. Gradientul de altitudine, precum și fluctuațiile salinității nu afectează în mod semnificativ dinamica spațială a saturației de oxigen în ecosistemele acvatice din Republica Moldova. Pe de altă parte, gradientul latitudinal al temperaturii apei în granițele RM poate afecta valoarea acestui parametru. Relația directă între gradul de saturație a apei cu oxigen și temperatura apei determină analiza datelor în aspect sezonier. Fluctuațiile sezoniere ale saturației cu oxigen a apei fluviului Nistru și acumulării Dubăsari, în perioada februarie - octombrie 2020, sunt prezentate în Fig. 3.

Rezultatele obținute arată că saturația apei cu oxigen în iarna anului 2020 a fost adecvată pentru funcționarea ecosistemului acvatic, și anume: 84-
94 (\% saturație), clasa I de calitate. Expediția de primăvara a descoperit o zonă cu deficiența oxigenului în sectorul inferior al Nistrului - la stația Palanca (saturația $54 \%$, clasa de calitate III). Datorită situației hidrologice, scurgerea apei din lacul de acumulare Dnestrovsc în iunie și iulie a fost satisfăcătoare pentru ecosistemul fl. Nistru, și saturația apei cu oxigen a corespuns claselor I - II de calitate. Dinamica spațială a saturației oxigenului în condițiile debitului scăzut al Nistrului (august, octombrie 2020) a fost observată de mulți ani: deficiența de oxigen la stația Naslavcea (49 54 \% de saturație) și o creștere a saturației până la stația Camenca. Este aceeași dinamică ca și în cazul pH-ului.

Saturația apei cu oxigen în acumularea Dubăsari, pe parcursul perioadei de vegetație, variază într-un diapazon destul de larg: 70 - 130 (\% de saturație). Suprasaturarea cu oxigen $(>100 \%)$ a fost înregistrată în stratul fotic al apei în sezonul de vară (Fig. 3, Cocieri). Atât în cazurile de deficit de oxigen, cât și în cazurile de suprasaturare, nivelurile critice ale acestui indicator de calitate pentru apele dulci de suprafață - limită inferioară de 40 \% și limită superioară de 150 \% [12] - nu au fost atinse. Astfel, datorită specificului condițiilor hidrologice în anul 2020, deficitul oxigenului în ecosistemul fl. Nistru, inclusiv lacul de acumulare Dubăsari a fost înregistrat numai pentru două stații: Palanca (mai) și sectorul Naslavcea - Vălcineț (august, octombrie). Similitudinea dinamicii, de la redusă la fondul natural, a parametrilor „reacția activă a apei” și „oxigenul dizolvat ” confirmă modificarea semnificativă a Nistrului ca ecosistem în tronsonul Naslavcea - Camenca. 


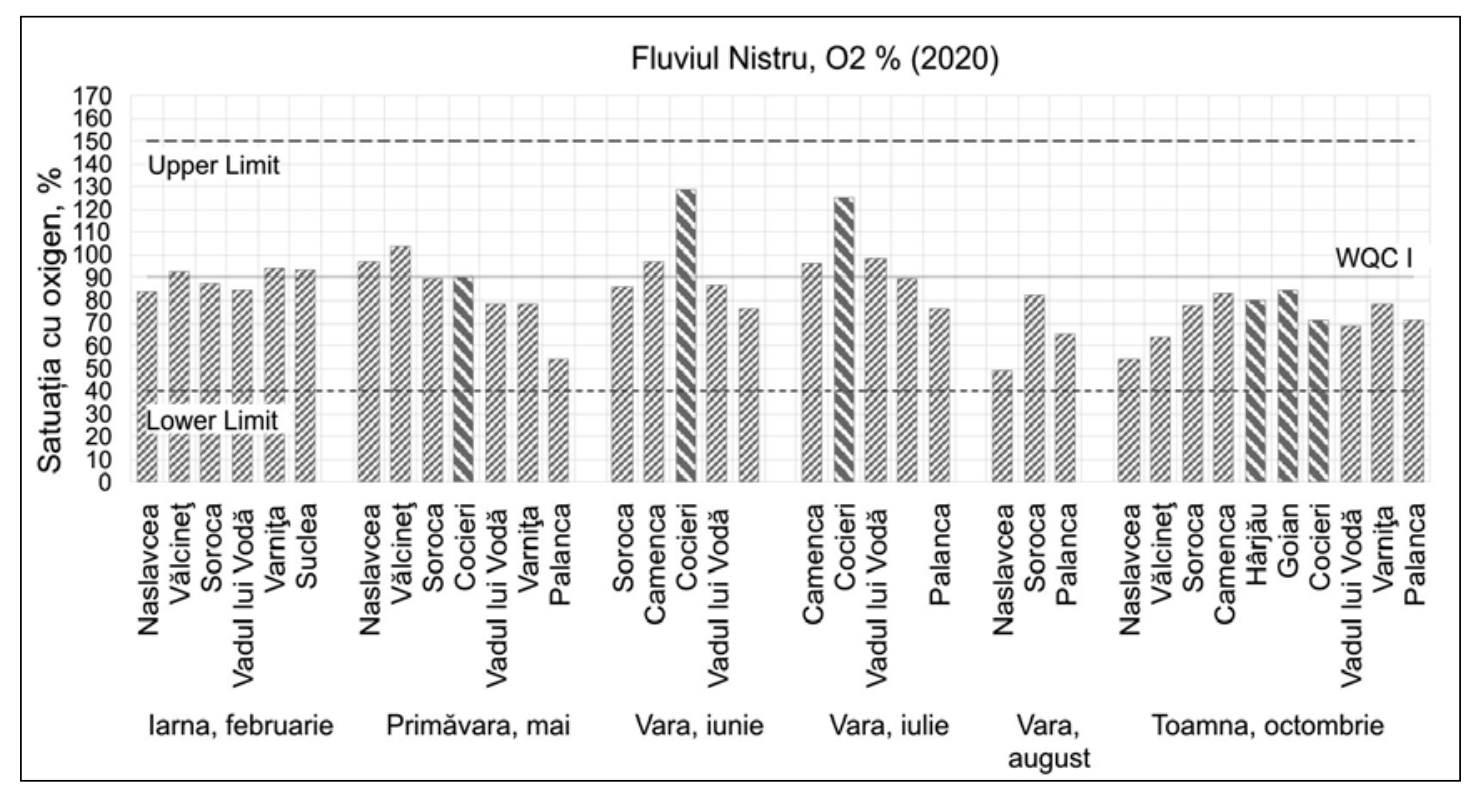

Fig. 3. Variațiile sezoniere ale saturației oxigenului în apa fl. Nistru și lacului de acumulare Dubăsari (Hârjău, Goian, Cocieri)

Parametrul "consumul biochimic de oxigen" (CBO), de asemenea, caracterizează starea regimului de oxigen al ecosistemului acvatic împreună cu parametrii "oxigen dizolvat " și "consumul chimic de oxigen ". Metoda de determinare a CBO simulează procesul de auto-purificare a apei în condiții de laborator. Parametrul este utilizat pe scară largă în sistemele de clasificare a apelor de suprafață, precum și pentru controlul tehnologic de epurare a apelor uzate. Dinamica sezonieră a valorilor testului $\mathrm{BOD}_{5}$ reflectă o dependență multifactorială de fluctuațiile sezoniere ale temperaturii apei, conținutul de oxigen dizolvat, existența poluanților, starea comunităților bacteriene etc. Concentrația substanțelor biodegradabile în apa fl. Nistru, și acumularea Dubăsari, nu a depășit valoarea-limită a clasei I de calitate $\left(3 \mathrm{mg} / \mathrm{L} \mathrm{O}_{2}\right)$. În cadrul acestei clase, $s$-au înregistrat valori mai scăzute ale $\mathrm{CBO}_{5}$ pentru tronsonul Naslavcea-Vălcineț. Analizând rezultatele prezentate de mai sus privind poluarea termică și saturația cu oxigen, devine clar că condițiile habitatului din acest sector al Nistrului nu sunt adecvate pentru dezvoltarea comunităților de microorganisme care desfășoară procesul de mineralizare a substanțelor biodegradabile. Prin urmare, potențialul ecosistemului pentru auto-purificare în această zonă a Nistrului este scăzut. Analiza datelor prezentată în Figura 4 include, de asemenea, informații despre conținutul substanțelor biodegradabile care intră în fluviul Nistru cu apele afluenților Răut și Bâc. Starea ecologică a principalilor afluenți ai Nistrului pe

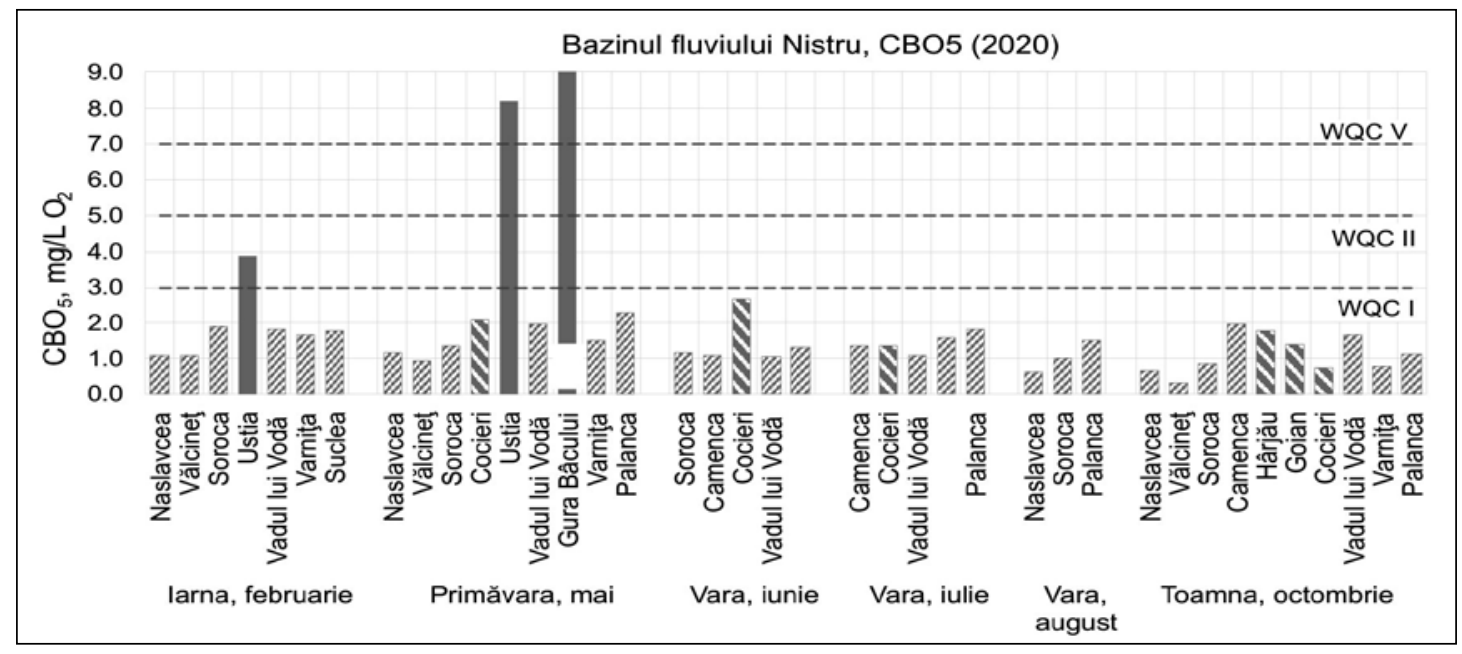

Fig. 4. Variațiile sezoniere ale consumului biochimic de oxigen (CBO5) în apa fluviului Nistru, lacului de acumulare Dubăsari (Hârjău, Goian, Cocieri) și afluenților de dreapta (Ustia - r. Răut, Gura Bâcului - r. Bâc) 
teritoriul Republicii Moldova lasă de dorit și mai ales în perioada caldă.

Rezultatele prezentate ne permit să concluzionăm: în ciuda faptului că concentrația de poluanți organici în afluenți este de multe ori mai mare decât cea din râul Nistru, datorită efectului de diluare și capacității de tampon a ecosistemului fl. Nistru, deja la următoarea stație indicatorul $\mathrm{BOD}_{5}$ revine la limitele clasei I de calitate. Analiza coeficientului de corelație permite determinarea puterii și direcției corelației dintre doua serii de observații simultane.
Într-un ecosistem acvatic neafectat, puterea și direcția relației între temperatura apei, concentrația oxigenului, starea de acidificare și consumul biochimic de oxigen, sunt determinate de procesele naturale. Comparând coeficienții de corelație obținuți cu cei pentru sectoare de referință, se poate vedea care condiții ale habitatului sunt cele mai perturbate într-un corp de apă studiat. În acest caz, neavând date pe site-ul de referință, am comparat rezultatul analizei de corelație pentru aceiași parametri în două ecosisteme -fl. Nistrul și r. Prut (Tab. 1)

Tab. 1. Coeficienții de corelație între parametrii fizico-chimici pentru fl. Nistru și r. Prut

\begin{tabular}{|c|c|c|c|c|c|c|}
\hline Nistru, 2020 & $\mathrm{~T}_{1}^{\circ}{ }^{\circ} \mathrm{C}$ & $\mathrm{O}, \mathrm{mg} / \mathrm{L}$ & $\mathrm{CBO}_{5}, \mathrm{mg} / \mathrm{L} \mathrm{O}_{2}$ & $\mathrm{pH}$ & \multicolumn{2}{|c|}{ Interpretarea semnificației } \\
\hline $\mathrm{T},{ }^{\circ} \mathrm{C}$ & 1 & & & & & \\
\hline $\mathrm{O}_{2}, \mathrm{mg} / \mathrm{L}$ & -0.638 & 1 & & & $0,0-0,3$ & foarte slab \\
\hline $\mathrm{CBO}_{5}, \mathrm{mg} / \mathrm{L} \mathrm{O}_{2}$ & -0.053 & 0.285 & 1 & & & \\
\hline $\mathrm{pH}$ & -0.601 & 0.755 & 0.225 & 1 & $0,3-0,5$ & slab \\
\hline \multicolumn{7}{|c|}{ numărul de probe $=35$} \\
\hline Prut, 2020 & $\mathrm{~T},{ }^{\circ} \mathrm{C}$ & $\mathrm{O}_{2}, \mathrm{mg} / \mathrm{L}$ & $\mathrm{CBO}_{5}, \mathrm{mg} / \mathrm{L} \mathrm{O}_{2}$ & $\mathrm{pH}$ & $0,5-0,7$ & mediu \\
\hline $\mathrm{T}^{\circ} \mathrm{C}$ & 1 & & & & & \\
\hline $\mathrm{O}_{2}, \mathrm{mg} / \mathrm{L}$ & -0.937 & 1 & & & $0,7-0,9$ & ridicat \\
\hline $\mathrm{CBO}_{5}, \mathrm{mg} / \mathrm{L} \mathrm{O}_{2}$ & -0.589 & 0.503 & 1 & & & \\
\hline $\mathrm{pH}$ & -0.819 & 0.887 & 0.410 & 1 & $0,9-1,0$ & puternic \\
\hline
\end{tabular}

Ambele ecosisteme sunt caracterizate printr-o corelație directă și puternică $(0,76-0,89)$ între parametrii " $\mathrm{O}_{2}$ " și "pH", ceea ce este clar, deoarece în în rezultatul fotosintezei producătorilor primari, concentrația $\mathrm{O}_{2}$ în apă crește, iar concentrația de $\mathrm{CO}_{2}$ scade, ceea ce duce la alcalinizarea mediului. Corelația inversă între parametrii "T" și " $\mathrm{O}_{2}$ ” este înaltî în în ecosistemul r. Prut $(-0,94)$, iar în fl. Nistru, această corelație (-0.64) este influențată de poluare termică pe sectorul Naslavcea - Soro- ca. Corelația inversă între parametrii "T" și "pH" este clasică fiind mai pronunțată în ecosistemele acvatice, unde procesele de descompunere a substanțelor biodegradabile sunt mai intense. Corelația între parametrii " $\mathrm{O}_{2}$ ” și " $\mathrm{CBO}_{5}$ ” nu este liniară, prin urmare poate fi directă sau inversă - în funcție de influența simultană a factorilor naturali și de impactul antropogen (Fig. 5). Aceeași argumentare se aplică și pentru corelația parametrilor "T" și ” $\mathrm{CBO}_{5}$ ”.
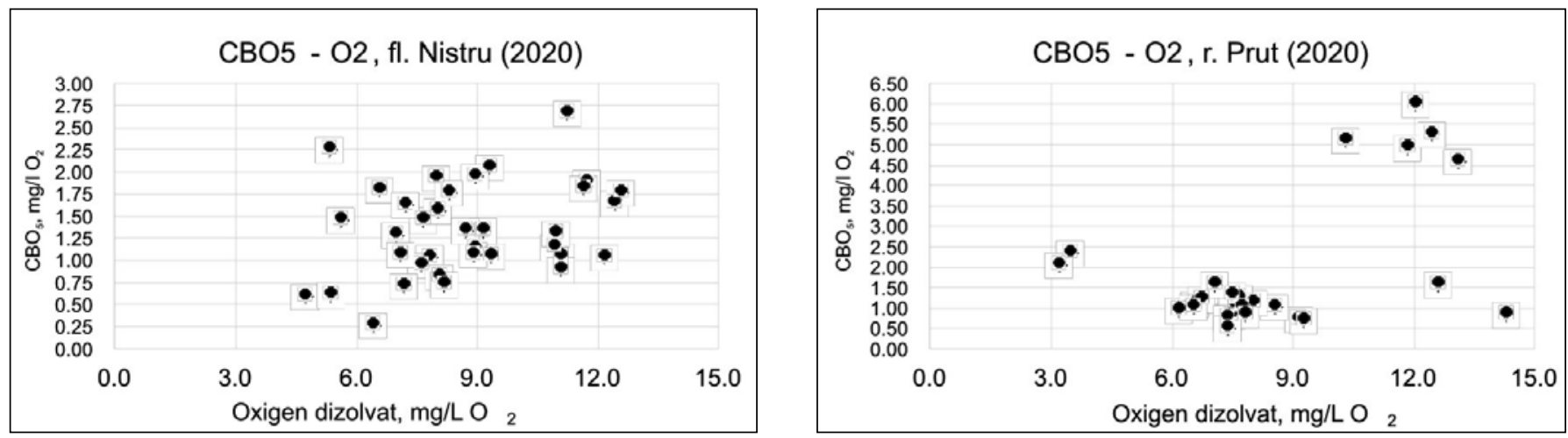

Fig. 5. Dispersia (Scatter Chart) pentru variabile $\left(\mathrm{CBO}_{5}\right.$ și $\left.\mathrm{O}_{2}\right)$ cu o relație neliniară 


\section{CONCLUZII}

Analiza datelor obținute indică existența unor schimbări semnificative în starea ecosistemului acvatic pe secțiunea Naslavcea - Camenca, cauzate de utilizarea apei Nistrului pentru producerea energiei electrice pe teritoriul Ucrainei. Modificarea regimului de temperatură al fluviului, în conformitate cu prevederile DCA, este estimată ca o poluare termică. O astfel de modificare afectează și alți parametri ai ecosistemului acvatic, de care depind condițiile pentru supraviețuire a organismelor acvatice, cum ar fi reacția activă a apei și concentrația oxigenului dizolvat. Dinamica proceselor producțional-distrucționale depinde, de asemenea, direct de regimul termic al ecosistemului acvatic. Dar dacă poluarea termică afectează o anumită secțiune a râului, atunci schimbările climatice afectează starea apelor de suprafață la diferite niveluri: atât la nivelul unui corp de apă, cât și la nivelul bazinului în ansamblu. Secetele hidrologice au devenit un fenomen obișnuit pe teritoriul Republicii Moldova, iar acum nu numai vara, ci și în alte anotimpuri. Râurile mici suferă cel mai mult: unele se usucă complet, în altele concentrația de poluanți depășește valorile-limită a clasei 5 -a de calitate. După cum rezultă din rezultatele acestui an, râul Nistru are încă suficient potențial pentru a purifica apele pe care le folosim și pentru a ne oferi posibilitatea de a utiliza alte servicii ecosistemice.

Investigațiile sunt realizate în cadrul proiectului 20.80009.7007.06 "Determinarea schimbărilor mediului acvatic, evaluarea migrației și impactului poluanților, stabilirea legităților funcționării hidrobiocenozelor și prevenirea consecințelor nefaste asupra ecosistemelor" (Programul de Stat 2020-2023) și a proiectelor BSB 27 și BSB 165 finanțate de Uniunea Europeană (Programul Operațional Comun "Bazinul Mării Negre 2014-2020”).

\section{REFERINȚE}

1. SM SR EN ISO 5667-1:2011 Calitatea apei. Prelevare. Partea 1: Ghid general pentru stabilirea programelor si tehnicilor de prelevare (in Romanian). Chișinău: INSM, 2011.

2. SM SR ISO 5667-4:2007 Calitatea apei. Prelevare. Partea 4: Ghid de prelevare a apelor din lacuri naturale și artificiale (in Romanian). Chișinău: MOLDOVA-STANDARD, 2007.

3. SM SR ISO 5667-6:2011 Calitatea apei. Prelevare. Partea 6: Ghid pentru prelevările efectuate în râuri și alte cursuri de apă (in Romanian). Chișinău: INSM, 2011.

4. Hydrochemical and hydrobiological sampling guidance. Chișinău: «Elan Poligraf», 2015.

5. SM SR EN 25813:2011 Calitatea apei. Determinarea conținutului de oxigen dizolvat. Metoda iodometrică. Chișinău: INSM, 2011.

6. SM SR EN 1899-2:2007 Calitatea apei. Determinarea consumului biochimic de oxigen după $n$ zile (CBOn). Partea 2: Metoda pentru probe nediluate. MOLDOVA-STANDARD, 2007.

7. SM SR ISO 10523:2014. Calitatea apei. Determinarea pH-lui. Chișinău: INSM, 2014.

8. Regulamentul cu privire la cerințele de calitate pentru apele de suprafață. HG RM nr. 890 din 12.11.2013. In: Monitorul Oficial nr. 262 - 267, 22 noiembrie 2013.

9. http://www.meteo.md/images/uploads/pages images_inline/Buletin_hidro.pdf.

10. ШЕВЦОВА, Л.В., БРУМА, И.Х., КУЗЬКО, О.А., ШАРАПАНОВСКАЯ, Т.Д., ТКАЧЕНКО, В.А., ЖДАНОВА, Г.А., АФАНАСЬЕВ, С.А. Гидрологическая характеристика трансграничного участка Среднего Днестра. В: Гидробиологический журнал, 1999, т. 35, № 2. Киев, 1999.

11. BULAT, D. Ihtiofauna Republicii Moldova: gene$z a$, starea actuală, tendințe și măsuri de ameliorare. Teza de doctor habilitat în științe biologice. Chișinău, 2019.

12. ОКСИЮК, О. П., ЖУКИНСКИЙ, В. Н., БРАГИНСКИЙ, Л. П., ЛИННИК, П. Н., КУЗЬМЕНКО, М. И., КЛЕНУС, В. Г. Комплексная экологическая классификация качества поверхностных вод суши В: Гидробиологический журнал, т. 29, 1993, № 4. Киев, Институт гидробиологии НАН Украины, 1993. 